\section{Silicon and oxygen isotopes unravel quartz formation processes in the Icelandic crust}

\author{
B.I. Kleine ${ }^{1 *}$, A. Stefánsson², S.A. Halldórsson¹, M.J. Whitehouse ${ }^{3}$, K. Jónasson ${ }^{4}$
}

Abstract

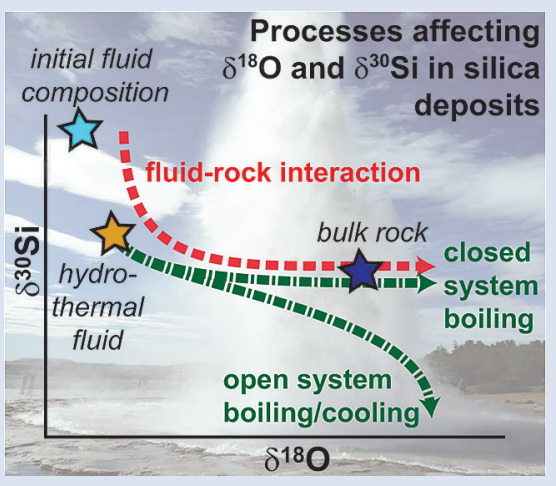

Quartz formation processes in the Icelandic crust were assessed using coupled $\delta^{18} \mathrm{O}$ and $\delta^{30} \mathrm{Si}$ systematics of silica deposits formed over a wide temperature range $\left(<150\right.$ to $\left.>550{ }^{\circ} \mathrm{C}\right)$. Magmatic quartz reveals $\delta^{18} \mathrm{O}(-5.6$ to $+6.6 \%)$ and $\delta^{30} \mathrm{Si}$ $(-0.4 \pm 0.2 \%$ o values representative of mantle- and crustally-derived melts in Iceland. Hydrothermal quartz and silica polymorphs display a larger range of $\delta^{18} \mathrm{O}(-9.3$ to $+30.1 \%$ o $)$ and $\delta^{30} \mathrm{Si}(-4.6$ to $+0.7 \%$ ) values. Isotope modelling reveals that such large variations are consistent with variable water sources and equilibrium isotope fractionation between fluids and quartz associated with secondary processes occurring in the crust, including fluid-rock interaction, boiling and cooling. In context of published $\delta^{18} \mathrm{O}$ and $\delta^{30} \mathrm{Si}$ data on hydrothermal silica deposits, we demonstrate that large ranges in $\delta^{30} \mathrm{Si}$ values coupled to insignificant $\delta^{18} \mathrm{O}$ variations may result from silica precipitation in a hydrothermal fluid conduit associated with near-surface cooling. While equilibrium isotope fractionation between fluids and quartz seems to prevail at high temperatures, kinetic fractionation likely influences isotope systematics at low temperatures.

Received 25 September 2017 | Accepted 12 March 2018 | Published 3 April 2018

\section{Introduction}

Quartz is among the most abundant minerals in the continental crust and a major constituent of many plutonic, sedimentary and metamorphic rocks (e.g., Götze, 2009). Under magmatic conditions, quartz may crystallise at $\sim 700{ }^{\circ} \mathrm{C}$ and numerous metamorphic reactions involve the consumption and production of quartz. Because of its common association with hydrothermal and ore deposits, the origin of quartz and its paragenesis continues to be a subject of considerable discussion.

Over the past decades, oxygen isotopes have been applied as a tracer for the source(s) of crustal fluids (e.g., Bowman et al., 1994). However, Si isotopes have only gained interest recently due to improved analytical techniques. Silicon isotopes of quartz and other silica polymorphs range from -5 to $+5 \%$ and have been used for reconstruction of past geological environments (Fig. 1). $\delta^{30} \mathrm{Si}$ systematics in Precambrian chert deposits have been used to constrain environmental conditions during their formation (e.g., Robert and Chaussidon, 2006; MarinCarbonne et al., 2014). However, silicon isotope data from more recent quartz deposits formed under variable temperatures and fluid compositions, are still limited (Geilert et al., 2015). Such data are critical to constrain the processes (e.g., fluid-rock interaction) that lead to the formation of secondary quartz in the Earth's crust, and can contribute to better understand the origin and formation conditions of ancient silica deposits.

Often adopted as a potential analogue for Earth's earliest continental crust (Reimink et al., 2014), the Icelandic crust represents a continental-type crust with characteristics typical of the oceanic crust. Iceland's crustal lithology is dominated by basalts with silicic volcanics and volcaniclastic sediments also being common (Sæmundsson, 1979). Hydrothermal activity occurs over a wide temperature range $(<10$ to $>400{ }^{\circ} \mathrm{C}$; Arnórsson et al., 2008), resulting in low-grade metamorphism within the crust (Kristmannsdóttir, 1979). Quartz is a common secondary mineral in hydrothermal systems whereas primary quartz is not common within the dominantly basaltic crust (Browne, 1978). This makes Iceland an ideal locality for studying secondary quartz formation processes taking place in the crust.

To assess quartz formation processes over a wide temperature range $\left(<150\right.$ to $\left.>550{ }^{\circ} \mathrm{C}\right), \delta^{18} \mathrm{O}$ and $\delta^{30} \mathrm{Si}$ isotopic and chemical composition in quartz and silica polymorphs from magmatic and hydrothermal settings in Iceland were studied using secondary ion mass spectrometry (SIMS) and electron microprobe analysis (EMPA). Applying isotope modelling approaches (Stefánsson et al., 2017), fluid sources, chemical

\footnotetext{
1. Nordic Volcanological Center, Institute of Earth Sciences, University of Iceland, Reykjavik, Iceland

2. Institute of Earth Sciences, University of Iceland, Reykjavik, Iceland

3. Swedish Museum of Natural History, Stockholm, Sweden

4. Icelandic Institute of Natural History, Garðabær, Iceland

Corresponding author (email: barbarak@hi.is)
} 
reactions and associated isotope fractionations were quantified for various processes occurring in the curst, including fluidrock interaction, fluid phase separation (boiling) and cooling. Implications of this dataset and the isotope modelling were further extended to explain the origin of ancient hydrothermal silica deposits.

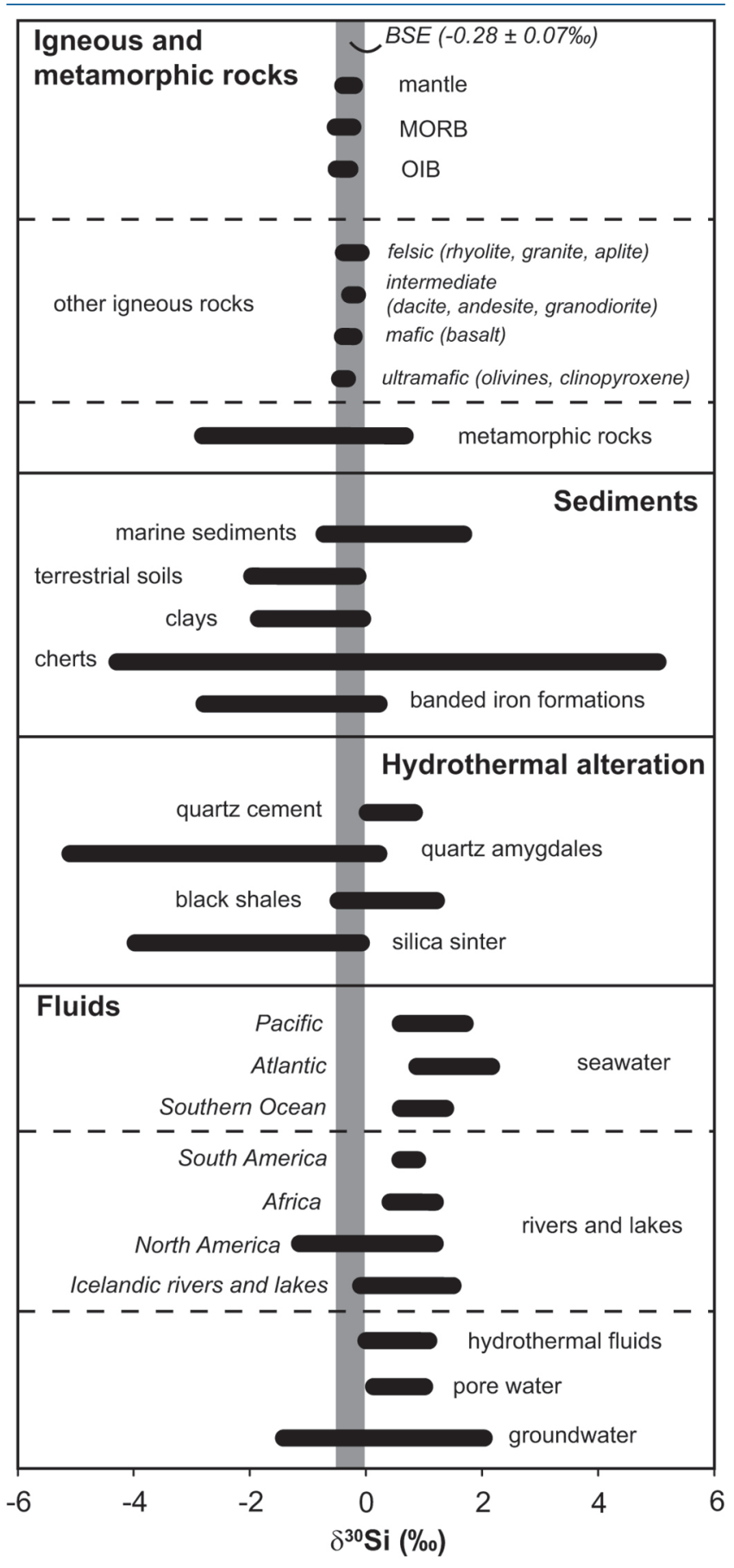

Figure 1 Compilation of $\delta^{30} \mathrm{Si}$ values for different rock types and fluids. Data taken from Douthitt (1982), De La Rocha et al. (2000), André et al. (2006), Robert and Chaussidon (2006), Georg et al. (2007a,b, 2009), Fitoussi et al. (2009), Steinhoefel, et al. (2009, 2010), Savage et al. (2010, 2011, 2012), Van den Boorn et al. (2010), Abraham et al. (2011), Armytage et al. (2011), Heck et al. (2011), Chakrabarti et al. (2012), Delvigne et al. (2012), Marin-Carbonne et al. (2012, 2014), Opfergelt et al. (2012), von Strandmann et al. (2012), Fan et al. (2013), Zambardi et al. (2013), Geilert et al. (2015), Stefurak et al. (2015), Brengman et al. (2016), Chen et al. (2016), Pollington et al. (2016). BSE = bulk silica earth (see Supplementary Information for more details).

\section{Methods and Results}

Quartz-bearing samples were collected from multiple locations throughout Iceland (Fig. S-1) including (1) magmatic (primary) quartz $(n=9)$ associated with crustal xenoliths and micro-granites $\left(>550{ }^{\circ} \mathrm{C}\right)$, (2) hydrothermal (secondary) hightemperature quartz ( 200 to $\left.400{ }^{\circ} \mathrm{C} ; \mathrm{n}=48\right)$ and (3) hydrothermal low-temperature quartz and silica polymorphs $\left(<150{ }^{\circ} \mathrm{C} ; \mathrm{n}=20\right)$. Oxygen $\left(\delta^{18} \mathrm{O}_{\mathrm{V}-\mathrm{SMOW}}\right)$ and silicon $\left(\delta^{30} \mathrm{Si}_{\mathrm{NBS} 28}\right)$ isotope composition of quartz and silica polymorphs were analysed in situ using SIMS and trace elements of the same grains using EMPA. Details on sample selection, processing, analysis and results are given in the Supplementary Information (SI).

Oxygen isotopes in magmatic quartz display $\delta^{18} \mathrm{O}$ values of -5.6 to $+6.6 \%$, while silicon isotopes show a very limited range of $\delta^{30} \mathrm{Si}$ values of -0.7 to $-0.2 \%$ (Fig. 2). In contrast, both $\delta^{18} \mathrm{O}\left(-9.3\right.$ to $+30.1 \%$ ) and $\delta^{30} \mathrm{Si}(-4.6$ to $+0.5 \%$ o) of hydrothermal quartz display a much greater range. Trace element concentrations of quartz agree with existing quartz data from other magmatic and hydrothermal settings (Götze, 2009; Table S-2). Al and Ti in magmatic quartz range from 57 to $77 \mathrm{ppm}$ and 56 to $140 \mathrm{ppm}$, respectively, while Al and $\mathrm{Ti}$ in hydrothermal quartz and silica polymorphs span a wide range $(\mathrm{Al}=28-2140 \mathrm{ppm} ; \mathrm{Ti}=20-80 \mathrm{ppm})$. Additionally, trace element concentrations in hydrothermal quartz do not show any distinct correlation with $\delta^{18} \mathrm{O}$ and $\delta^{30} \mathrm{Si}$ that would allow us to further distinguish different formation conditions (Fig. S-3).

\section{Controls on $\delta^{18} \mathrm{O}$ and $\delta^{30} \mathrm{Si}$ in Hydrothermal Quartz}

Oxygen and silicon isotope values of both ancient and modern hydrothermal silica deposits vary significantly with $\delta^{18} \mathrm{O}$ ranging from -10 to $+30 \%$ and $\delta^{30}$ Si ranging from -5 to +2 \%o (Geilert et al., 2015; Brengman et al., 2016; Pollington et al., 2016; this study). Silica and oxygen are both reactive elements and their isotope ratios in minerals and fluids may change significantly upon crustal processes and associated chemical reactions. The observed wide range in isotopic values of hydrothermal silica deposits highlights the need for quantification of such processes and their effects on the isotope systematics. Processes of importance in hydrothermal systems include fluid-rock interaction, phase separation (boiling) and temperature changes (cooling). Such processes lead to changes in the relative abundance of elements of various sources, e.g., the water to rock ratio, changes in aqueous species and gas concentrations and quantity of secondary minerals formed, which may all influence isotopic characteristics of fluids and minerals (Stefánsson et al., 2017).

\section{Origin of Primary $\delta^{18} \mathrm{O}$ and $\delta^{30} \mathrm{Si}$ Characteristics}

The $\delta^{18} \mathrm{O}$ values of igneous rocks in Iceland are generally thought to represent derivation from a mantle source ranging in $\delta^{18} \mathrm{O}$ from +5 to $+6 \%$ (Hemond et al., 1993). However, as a result of extensive fluid-rock interaction involving a low $-{ }^{18} \mathrm{O}$ meteoric water component, strong $\delta^{18} \mathrm{O}$-depletions from such a mantle source are commonly observed in Icelandic rocks (Muehlenbachs et al., 1974). Such fluid-rock interaction likely affected xenoliths from the 1875 Askja eruption from our sample suite that show notable depletion in $\delta^{18} \mathrm{O}(-5.5 \pm 0.4 \%$; Fig. 2a). 

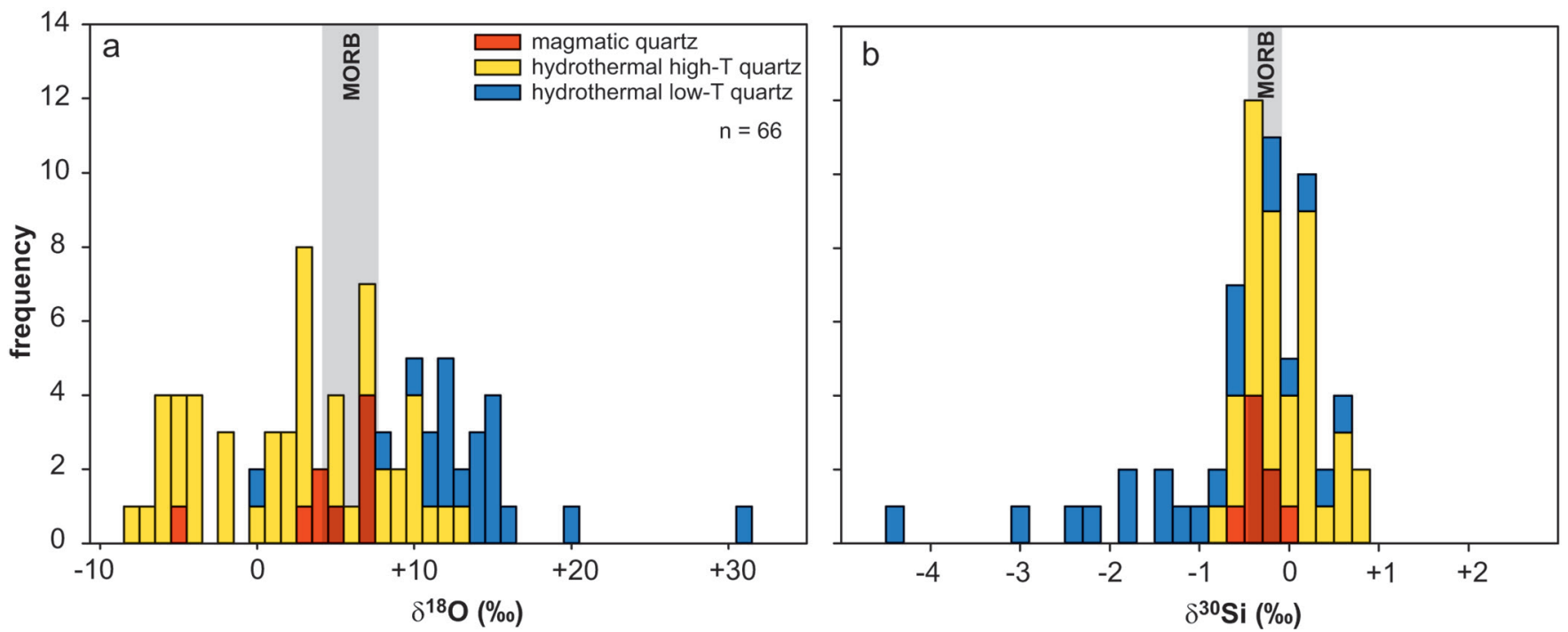

Figure 2 Variation in (a) $\delta^{18} \mathrm{O}$ and (b) $\delta^{30} \mathrm{Si}$ values of magmatic quartz $\left(>550{ }^{\circ} \mathrm{C}\right)$, hydrothermal high-temperature $\left(\sim 200-400{ }^{\circ} \mathrm{C}\right)$ quartz and low-temperature $\left(<150{ }^{\circ} \mathrm{C}\right)$ quartz and other silica polymorphs. The isotopic values are compared to $\delta^{18} \mathrm{O}$ and $\delta^{30} \mathrm{Si}$ values for MORB (Eiler et al., 2000; Savage et al., 2010).

Despite strong $\delta^{18} \mathrm{O}$-depletions in the Askja xenoliths, their $\delta^{30} \mathrm{Si}$ values display only a limited range (Fig. $2 b$ ). Indeed, $\delta^{30} \mathrm{Si}$ values measured in magmatic quartz $(-0.75$ to $-0.19 \%$ ) in this study agree with values reported for whole rock and glass samples of igneous rocks from Iceland and elsewhere (Figs. 1, 2b; Table S-1). Recent studies showed that the silicon isotopic composition of Earth's mantle is relatively homogenous $\left(\delta^{30} \mathrm{Si}=-0.29 \pm 0.07 \%\right.$ o) and not greatly affected by magmatic processes (Savage et al., 2010). As a result, the $\delta^{30} \mathrm{Si}$ values of magmatic quartz (this study) likely represent magmatic values. This implies that the measured $\delta^{30} \mathrm{Si}$ values have not been affected by interaction of the xenoliths with meteoric water and/or other secondary processes.

\section{Assessing Secondary Silica Mineralisa- tion Processes in the Icelandic Crust}

The large range in $\delta^{18} \mathrm{O}$ and $\delta^{30} \mathrm{Si}$ values of hydrothermal quartz and silica polymorphs (Fig. 2) are considered to reflect the source(s) of the elements and isotope fractionations associated with hydrothermal processes and reactions. These processes and their effects on the $\delta^{18} \mathrm{O}$ and $\delta^{30} \mathrm{Si}$ values in quartz can be quantified using isotope modelling approaches (Fig. 3a,b; detailed description in SI).

Comparison of our dataset with the results of the isotope models reveals that silica in hydrothermal high-temperature quartz predominantly originates from the primary (basaltic) rocks that generally display a limited range in $\delta^{30} \mathrm{Si}$ values $(-0.29 \pm 0.07 \%$; Savage et al., 2010, Fig. 3c,d). Upon progressive fluid-rock interaction, the silica is dissolved from the rock by the hydrothermal fluid and precipitates as hydrothermal quartz. The model predicts that the observed decrease in $\delta^{30} \mathrm{Si}$ values (+0.66 to $-1.01 \%$ ) compared to the isotopic values characteristic for basaltic rocks and meteoric water $(+0.68 \%$, Georg et al., 2007a) and/or seawater (+1.16 \%o; De La Rocha et al., 2000) results from isotope fractionation upon progressive fluid-rock interaction, boiling and cooling. In contrast, oxygen in quartz has multiple sources with the $\delta^{18} \mathrm{O}$ values dominated by the source water at low rock-water ratio $(\xi<0.1 \mathrm{~mol}$ basalt $/ \mathrm{kg}$ water) and the primary rock at high rock-water ratio $(\xi=0.1-10 \mathrm{~mol}$ basalt $/ \mathrm{kg}$ water; Figs. $3, \mathrm{~S}-4)$. The $\delta^{18} \mathrm{O}$ value of the source water also varies. Seawater can be approximated to a value of $0 \pm 1 \%$ (vSMOW), while meteoric water will depend on the geographical location, with values of $-7.5 \pm 1 \%$ o in the south but $-12.5 \pm 1 \%$ in the north of Iceland (Árnason, 1976).

Hydrothermal low-temperature quartz and silica polymorphs are typically formed by precipitation of dissolved silica upon cooling at or near the surface (e.g., Neuhoff et al., 1999; Geilert et al., 2015). In most cases, the source waters are high-temperature hydrothermal fluids with elevated silica concentrations (Geilert et al., 2015). The trends observed in Figure $3 \mathrm{~d}$ are consistent with these silica phases having $\delta^{30} \mathrm{Si}$ values similar to, or more negative than, the primary host rocks. The depletion of ${ }^{30} \mathrm{Si}$ in the silica minerals cannot be explained by simple fluid-rock interaction and equilibrium fractionation. According to our model, equilibrium fractionation associated with fluid-rock interaction would result in precipitation of quartz with $\delta^{30} \mathrm{Si}$ values ranging from +2 to $+0.5 \%$ and, depending on the fluid source, $\delta^{18} \mathrm{O}$ values of $+10 \pm 5 \%$ or $+15 \pm 5 \%$. Instead, the observed $\delta^{18} \mathrm{O}$ and $\delta^{30} \mathrm{Si}$ values follow a trend predicted by boiling of high-temperature hydrothermal fluids to surface $\left(100^{\circ} \mathrm{C}\right)$ followed by cooling (Fig. 3d). The model predicts that the fluid becomes progressively more negative in $\delta^{30} \mathrm{Si}$ than the corresponding silica minerals. However, recent measurements of silica precipitates and coexisting hydrothermal water suggest the opposite, i.e. that the boiled water is enriched in ${ }^{30} \mathrm{Si}$ relative to the solid precipitate (Geilert et al., 2015). In line with previous findings (Geilert et al., 2015; Roerdink et al., 2015; Brengman et al., 2016), this suggests that fractionation between silica deposits and fluids under low-temperature $\left(<150{ }^{\circ} \mathrm{C}\right)$ hydrothermal conditions is likely controlled by kinetics and may strongly depend on precipitation rates.

\section{Implications for Hydrothermal Silica deposits in the Geological Record}

Coupled $\delta^{18} \mathrm{O}$ and $\delta^{30} \mathrm{Si}$ studies of ancient hydrothermal silica are still rare (Brengman et al., 2016; Pollington et al., 2016). Hydrothermal quartz precipitates such as quartz amygdales encased by quartz cement occur in a brecciated pillow basalt from the Isua Greenstone Belt in SW Greenland and display a broad range of $\delta^{30} \mathrm{Si}$ values with insignificant variations of $\delta^{18} \mathrm{O}$ (Brengman et al., 2016). A similar isotopic trend has been observed in quartz cements of hydrothermal origin within the 

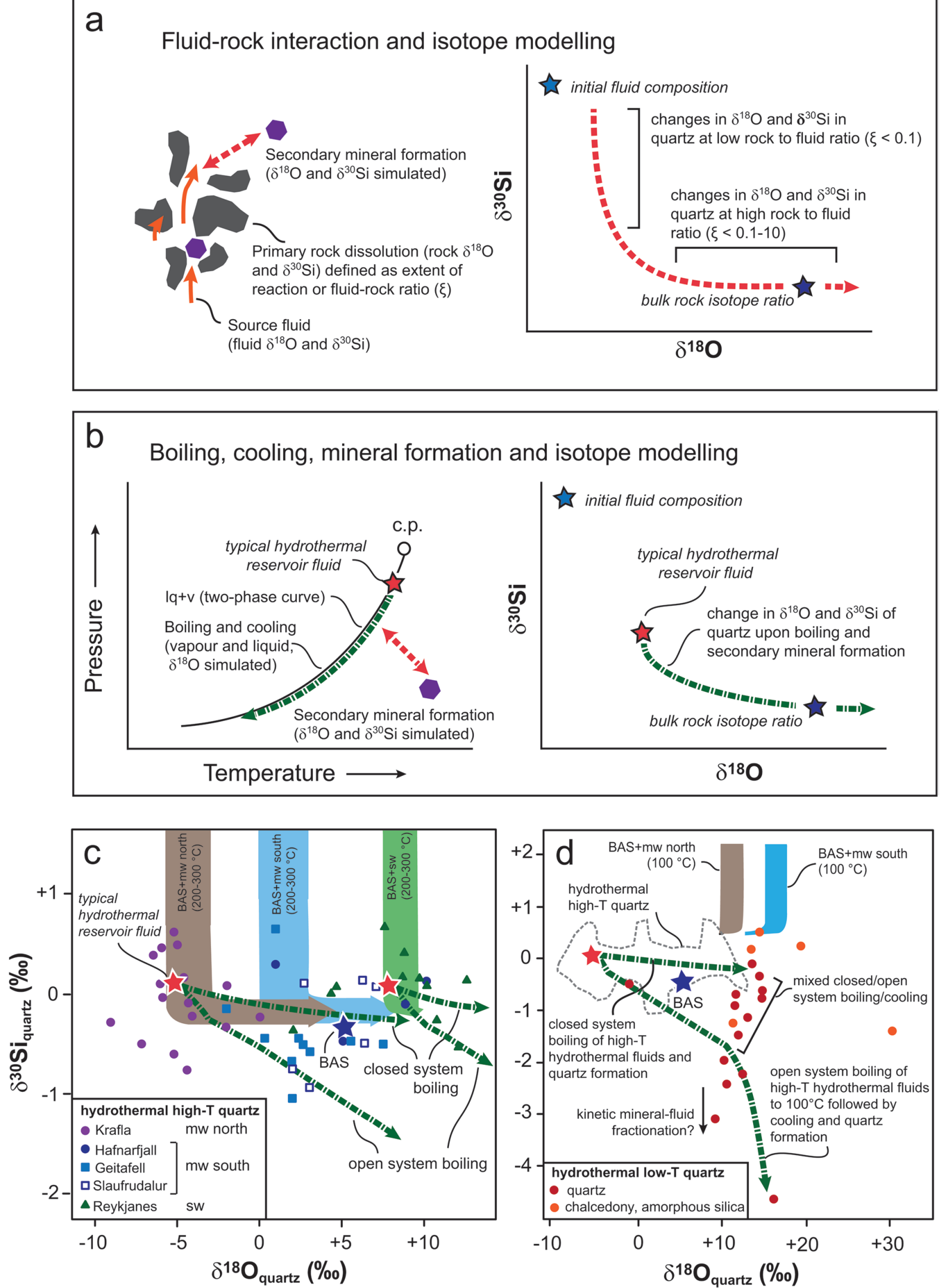

Figure 3 The conceptual chemical and isotope model involves (a) fluid-rock interaction with various source fluids and (b) boiling followed by cooling and mineral formation; (c) isotope systematics in hydrothermal high-temperature quartz largely match the predicted reaction path for progressive fluid-rock interaction (shaded areas) and boiling (arrows). $\delta^{30}$ Si decreases with increasing rock-fluid ratio $(\xi)$ whereas $\delta^{18} \mathrm{O}$ values in quartz both depend on the source water and rock-fluid ratio; (d) most of the isotope variations in hydrothermal low-temperature quartz and silica polymorphs can be explained by boiling and cooling of a hydrothermal fluid (arrows). Silica deposits with low $\delta^{30} \mathrm{Si}$ and constant $\delta^{18} \mathrm{O}$ values may result from open system boiling of a high-temperature fluid followed by cooling and quartz or opal formation. BAS = basalt, $\mathrm{mw}=$ meteoric water, sw = seawater. Analytical uncertainties of $\delta^{30} \mathrm{Si}$ and $\delta^{18} \mathrm{O}$ are listed in Tables S-7 and S-8. 


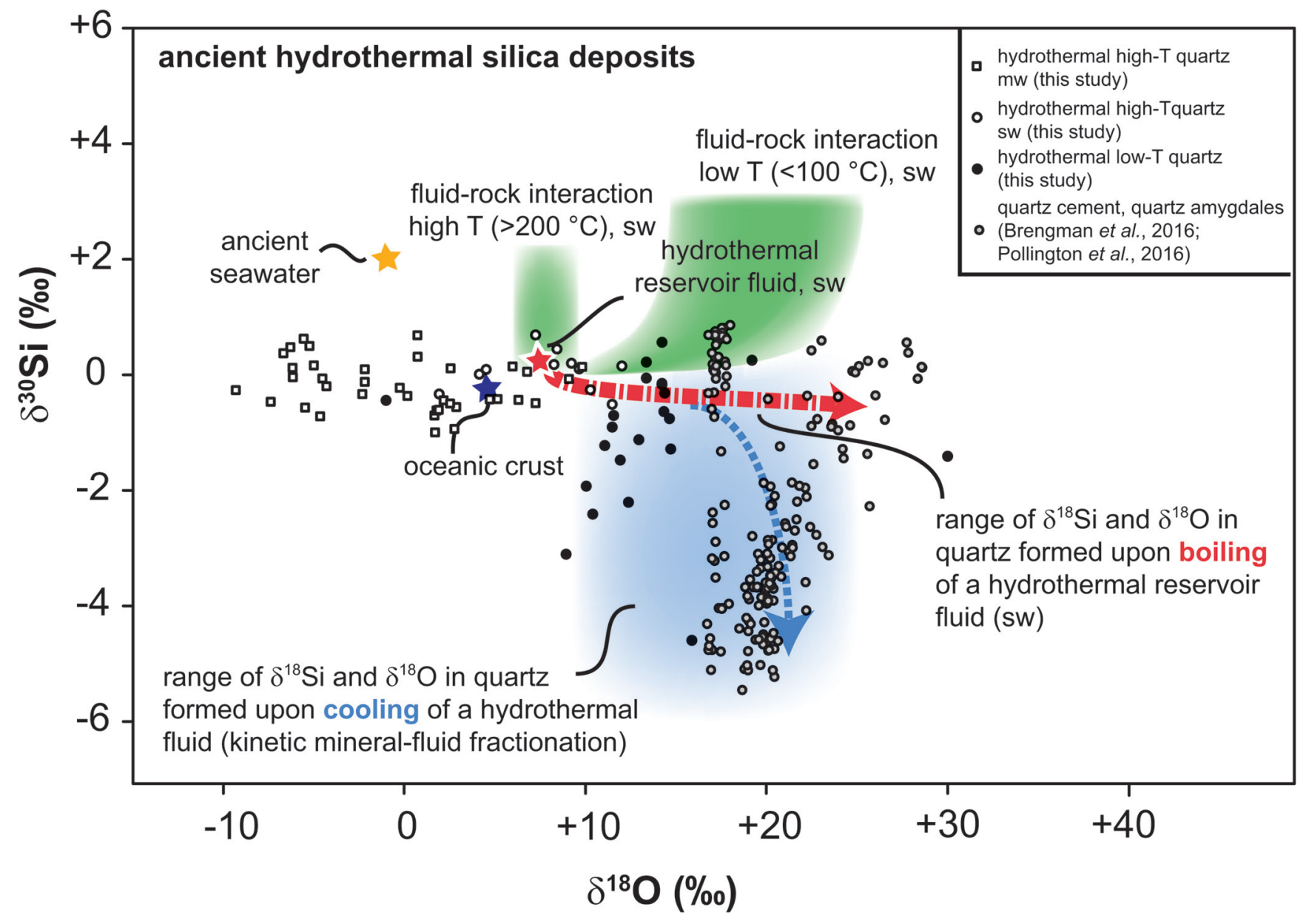

Figure $4 \delta^{30}$ Si versus $\delta^{18} \mathrm{O}$ values of ancient, hydrothermally altered quartz cement and amygdales (Brengman et al., 2016; Pollington et al., 2016). A highly variable but largely negative range in $\delta^{30} \mathrm{Si}$ values is likely to result from quartz precipitating out of a boiling and cooling fluid involving kinetic fluid-quartz/opal fractionation during rapid temperature decrease. For modelling, the isotope composition of ancient seawater was used (Marin-Carbonne et al., 2014). $\mathrm{mw}=$ meteoric water, $\mathrm{sw}=$ seawater.

Cambrian Mt. Simon Formation in central North America (Pollington et al., 2016). Such trends have been interpreted as the result of (1) rapid quartz formation from thermal fluids and kinetic isotope fractionation (Brengman et al., 2016) or (2) quartz cement precipitation from hydrothermal fluids that leached ${ }^{30} \mathrm{Si}$-depleted silicon from the surrounding highly weathered Precambrian rocks (Pollington et al., 2016). The results of the present study indicate that such trends are also typical for open system silica precipitation from a hydrothermal fluid conduit and near-surface cooling, where the chemical and isotope composition of the fluid and silicates changes along the fluid flow path (Fig. 4). Differences in $\delta^{18} \mathrm{O}$ values between silica deposits may not only result from varying temperature conditions but may also derive from variation in the source water. Furthermore, despite the sedimentary origin of cherts and banded iron formations (BIFs), these rocks have often been exposed to hydrothermal alteration (e.g., Van den Boorn et al., 2007). Thus, the interaction between seawater, hydrothermal fluids and host rocks might have an effect on the Si and $\mathrm{O}$ composition even in those silica deposits.

Despite the lack of fractionation factors between fluids and precipitating minerals, this study demonstrates that progressive fluid-rock interaction and the reactions involved may have a strong influence on the oxygen and silicon isotopic characteristics of hydrothermal fluids and associated secondary minerals over a wide temperature range. Fractionation between fluids and minerals of reactive elements like silicon and oxygen are dependent on the source(s) and chemical reactions, aqueous and gas speciation changes as well as secondary mineral formation. Such processes could lead to $\delta^{30} \mathrm{Si}$ and $\delta^{18} \mathrm{O}$ variations in hydrothermal silica deposits of $>2 \%$ and $>20 \%$, respectively, for a system dominated by a single source of both primary rock and water.

\section{Conclusions}

The $\delta^{18} \mathrm{O}$ and $\delta^{30} \mathrm{Si}$ systematics of quartz were determined in situ using SIMS to assess crustal quartz formation processes in Iceland. Magmatic quartz records $\delta^{18} \mathrm{O}$ of -5.6 to $+6.6 \%$ and $\delta^{30} \mathrm{Si}$ of $-0.4 \pm 0.2 \%$ representative of mantle- and crustally-derived melts in Iceland. Hydrothermal quartz and silica polymorphs $\left(<150\right.$ to $\left.400{ }^{\circ} \mathrm{C}\right)$ record a much greater range with $\delta^{18} \mathrm{O}$ of -9.3 to $+30.1 \%$ and $\delta^{30} \mathrm{Si}$ of -4.6 to $+0.7 \%$ o. Isotope modelling reveals that these large variations in the $\delta^{18} \mathrm{O}$ and $\delta^{30} \mathrm{Si}$ values are caused by a combination of processes such as fluid-rock interaction, cooling, boiling and associated changes in aqueous and gas speciation of the fluids as well as type and quantity of secondary minerals formed upon these processes. Comparison of the results of this study suggests that the large ranges observed in $\delta^{30} \mathrm{Si}$ values and insignificant $\delta^{18} \mathrm{O}$ variations observed in quartz cements and quartz amygdales of hydrothermal origin may result from silica formation in a hydrothermal fluid conduit at or near the surface associated with cooling. Equilibrium fractionation of $\delta^{18} \mathrm{O}$ and $\delta^{30} \mathrm{Si}$ between fluids and minerals seems to prevail at hydrothermal high-temperature conditions $\left(\sim 200-400{ }^{\circ} \mathrm{C}\right)$, whereas kinetic fractionation is likely to influence isotope systematics at lower temperatures. 


\section{Acknowledgements}

This project was financially supported by NordVulk and Landsvirkjun. HS Orka and Landsvirkjun kindly provided access to the drill cuttings. H. Franzson, J.S. Gunnarsdóttir, G.H. Guðfinnsson, S. Harðardóttir, M. Hermanska, L. Ilyinsky, K. Lindén, J. Prikryl and H. Sigurjónsson are thanked for assistance during field work, sample preparation and/or data acquisition. We thank J. Marin-Carbonne and an anonymous reviewer for their constructive reviews. A. Anbar is thanked for careful editorial handling. This is NordSIM contribution 551.

Editor: Ariel Anbar

\section{Additional Information}

Supplementary Information accompanies this letter at http:// www.geochemicalperspectivesletters.org/article1811.

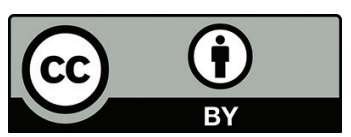

This work is distributed under the Creative Commons Attribution 4.0 License, which permits unrestricted use, distribution, and reproduction in any medium, provided the original author and source are credited. Additional information is available at http://www.geochemicalperspectivesletters.org/ copyright-and-permissions.

Cite this letter as: Kleine, B.I., Stefánsson, A., Halldórsson, S.A., Whitehouse, M.J., Jónasson, K. (2018) Silicon and oxygen isotopes unravel quartz formation processes in the Icelandic crust. Geochem. Persp. Let. 7, 5-11.

\section{References}

Abraham, K., Hofmann, A., Foley, S.F., Cardinal, D., Harris, C., BARTH, M.G., ANDré, L. (2011) Coupled silicon-oxygen isotope fractionation traces Archaean silicification. Earth and Planetary Science Letters 301, 222-230.

André, L., Cardinal, D., Alleman, L.Y., Moorbath, S. (2006) Silicon isotopes in $3.8 \mathrm{Ga}$ West Greenland rocks as clues to the Eoarchaean supracrustal Si cycle. Earth and Planetary Science Letters 245, 162-173.

Armytage, R.M.G., Georg, R.B., Savage, P.S., Williams, H.M., HallIDAY, A.N. (2011) Silicon isotopes in meteorites and planetary core formation. Geochimica et Cosmochimica Acta 75, 3662-3676.

ÁRNASON, B. (1976) Groundwater systems in Iceland traced by deuterium. Vísindafélag Îslendinga 42, 60-66.

ArNórsson, S., AXELSSON, G., SÆMUndsson, K. (2008) Hydrothermal systems in Iceland. Jökull 58, 269-302.

BoWman, J.R., Willett, S.D., CoOK, S.J. (1994) Oxygen isotopic transport and exchange during fluid flow: one-dimensional models and applications. American Journal of Science 294, 1-55.

Brengman, L.A., Fedo, C.M., Whitehouse, M.J. (2016) Micro scale silicon isotope heterogeneity observed in hydrothermal quartz precipitates from the $>3.7$ Ga Isua Greenstone Belt, SW Greenland. Terra Nova $28,70-75$

BROWNE, P.R.L. (1978) Hydrothermal alteration in active geothermal fields Annual Review of Earth and Planetary Sciences 6, 229-250.

Chakrabarti, R., Knoll, A.H., Jacobsen, S.B., Fischer, W.W. (2012) $\mathrm{Si}$ isotope variability in Proterozoic cherts. Geochimica et Cosmochimica Acta 91, 187-201.

Chen, X., Chafetz, H.S., Andreasen, R., Lapen, T.J. (2016) Silicon isotope compositions of euhedral authigenic quartz crystals: Implications for abiotic fractionation at surface temperatures. Chemical Geology $423,61-73$.

De La Rocha, C.L., Brzezinski, M.A., DeNiro, M.J. (2000) A first look at the distribution of the stable isotopes of silicon in natural waters. Geochimica et Cosmochimica Acta 64, 2467-2477.
Delvigne, C., Cardinal, D., Hofmann, A., André, L. (2012) Stratigraphic changes of $\mathrm{Ge} / \mathrm{Si}, \mathrm{REE}+\mathrm{Y}$ and silicon isotopes as insights into the deposition of a Mesoarchaean banded iron formation. Earth and Planetary Science Letters 355, 109-118.

DouthitT, C.B. (1982) The geochemistry of the stable isotopes of silicon. Geochimica et Cosmochimica Acta 46, 1449-1458.

Eiler, J.M., Schiano, P., Kitchen, N., Stolper, E.M. (2000) Oxygen isotope evidence for recycled crust in the sources of mid ocean ridge basalts. Nature 403, 530-534

FAN, H., Wen, H., ZHU, X., HU, R., TIAN, S. (2013) Hydrothermal activity during Ediacaran-Cambrian transition: Silicon isotopic evidence. Precambrian Research 224, 23-35.

Fitoussi, C., Bourdon, B., Kleine, T., Oberli, F., Reynolds, B.C. (2009) $\mathrm{Si}$ isotope systematics of meteorites and terrestrial peridotites: implications for $\mathrm{Mg} / \mathrm{Si}$ fractionation in the solar nebula and for Si in the Earth's core. Earth and Planetary Science Letters 287, 77-85.

Geilert, S., Vroon, P.Z., Keller, N.S., Gudbrandsson, S., Stefánsson, A., VAN BERGEN, M.J. (2015) Silicon isotope fractionation during silica precipitation from hot-spring waters: evidence from the Geysir hydrothermal field, Iceland. Geochimica et Cosmochimica Acta 164, 403-427.

Georg, R.B., Reynolds, B.C., West, A.J., Burton, K.W., Halliday, A.N. (2007a) Silicon isotope variations accompanying basalt weathering in Iceland. Earth and Planetary Science Letters 261, 476-490.

Georg, R.B., Halliday, A.N., Schauble, E.A., Reynolds, B.C. (2007b) Silicon in the Earth's core. Nature 447, 1102-1106.

Georg, R.B., Zhu, C., Reynolds, B.C., Halliday, A.N. (2009) Stable silicon isotopes of groundwater, feldspars, and clay coatings in the Navajo Sandstone aquifer, Black Mesa, Arizona, USA. Geochimica et Cosmochimica Acta 73, 2229-2241.

GÖTZE, J. (2009) Chemistry, textures and physical properties of quartz geological interpretation and technical application. Mineralogical Magazine 73, 645-671.

Heck, P.R., Huberty, J.M., Kita, N.T., Ushikubo, T., Kozdon, R., VALLEY, J.W. (2011) SIMS analyses of silicon and oxygen isotope ratios for quartz from Archean and Paleoproterozoic banded iron formations. Geochimica et Cosmochimica Acta 75, 5879-5891.

Hemond, C., Arndt, N.T., Lichtenstein, U., Hofmann, A.W., Oskarsson, N., Steinthorsson, S. (1993) The heterogeneous Iceland plume: $\mathrm{Nd} \mathrm{Sr} \mathrm{O}$ isotopes and trace element constraints. Journal of Geophyscal Research: Solid Earth 98, 15833-15850.

KRISTMANNSDÓTTIR, H. (1979) Alteration of Basaltic Rocks by Hydrothermal-Activity at $100-300^{\circ} \mathrm{C}$. Developments in sedimentology 27, 359-367.

Marin-Carbonne, J., Chaussidon, M., Robert, F. (2012) Micrometer-scale chemical and isotopic criteria $(\mathrm{O}$ and $\mathrm{Si})$ on the origin and history of Precambrian cherts: implications for paleo-temperature reconstructions. Geochimica et Cosmochimica Acta 92, 129-147.

Marin-Carbonne, J., Robert, F., Chaussidon, M. (2014) The silicon and oxygen isotope compositions of Precambrian cherts: A record of oceanic paleo-temperatures? Precambrian Research 247, 223-234.

Muehlenbachs, K., Anderson, A.T., Sigvaldason, G.E. (1974) Low-O18 basalts from Iceland. Geochimica et Cosmochimica Acta 38, 577-588.

Neuhoff, P.S., Fridriksson, T., Arnórsson, S., Bird, D.K. (1999) Porosity evolution and mineral paragenesis during low-grade metamorphism of basaltic lavas at Teigarhorn, Eastern Iceland. American Journal of Science 299, 467-501.

Opfergelt, S., Georg, R.B., Delvaux, B., Cabidoche, Y.-M., Burton, K.W., Halliday, A.N. (2012) Silicon isotopes and the tracing of desilication in volcanic soil weathering sequences, Guadeloupe. Chemical Geology 326, 113-122.

Pollington, A.D., Kozdon, R., Anovitz, L.M., Georg, R.B., SPicuzzA, M.J., VAlley, J.W. (2016) Experimental calibration of silicon and oxygen isotope fractionations between quartz and water at $250^{\circ} \mathrm{C}$ by in situ microanalysis of experimental products and application to zoned low $\delta^{30} \mathrm{Si}$ quartz overgrowths. Chemical Geology 421, 127-142.

Reimink, J.R., Chacko, T., Stern, R.A., Heaman, L.M. (2014) Earth's earliest evolved crust generated in an Iceland-like setting. Nature Geoscience 7, 529-533.

Robert, F., Chaussidon, M. (2006) A palaeotemperature curve for the Precambrian oceans based on silicon isotopes in cherts. Nature 443, 969-972.

Roerdink, D.L., VAN DEN BoOrn, S.H.J.M., Geilert, S., Vroon, P.Z., VAN BERGEN, M.J. (2015) Experimental constraints on kinetic and equilibrium silicon isotope fractionation during the formation of non-biogenic chert deposits. Chemical Geology 402, 40-51.

SÆMUNDSSON, K. (1979) Outline of the geology of Iceland. Jökull 29, 7-28. 
Savage, P.S., Georg, R.B., Armytage, R.M.G., Williams, H.M., HallIDAY, A.N. (2010) Silicon isotope homogeneity in the mantle. Earth and Planetary Science Letters 295, 139-146.

Savage, P.S., Georg, R.B., Williams, H.M., Burton, K.W., Halliday, A.N. (2011) Silicon isotope fractionation during magmatic differentiation. Geochimica et Cosmochimica Acta 75, 6124-6139.

Savage, P.S., Georg, R.B., Williams, H.M., Turner, S., Halliday, A.N., CHAPpelL, B.W. (2012) The silicon isotope composition of granites. Geochimica et Cosmochimica Acta 92, 184-202.

Stefánsson, A., Hilton, D.R., SveinbjÖRnsdóttir, Á.E., TorsSAnder, P., Heinemeier, J., Barnes, J.D., Ono, S., Halldórsson, S.A., FIEBIG, J., ARnÓRsson, S. (2017) Isotope systematics of Icelandic thermal fluids. Journal of Volcanology and Geothermal Research 337, 146-164.

Stefurak, E.J.T., Fischer, W.W., LOWE, D.R. (2015) Texture-specific Si isotope variations in Barberton Greenstone Belt cherts record low temperature fractionations in early Archean seawater. Geochimica et Cosmochimica Acta 150, 26-52.

Steinhoefel, G., Horn, I., von Blanckenburg, F. (2009) Micro-scale tracing of $\mathrm{Fe}$ and $\mathrm{Si}$ isotope signatures in banded iron formation using femtosecond laser ablation. Geochimica et Cosmochimica Acta 73, 5343-5360.

Steinhoefel, G., von Blanckenburg, F., Horn, I., Konhauser, K.O., BEUKES, N.J., GUTZMER, J. (2010) Deciphering formation processes of banded iron formations from the Transvaal and the Hamersley successions by combined $\mathrm{Si}$ and Fe isotope analysis using UV femtosecond laser ablation. Geochimica et Cosmochimica Acta 74, 2677-2696.

VAN DEN BOorn, S.H.J.M., VAN Bergen, M.J., NijMan, W., VROON, P.Z. (2007) Dual role of seawater and hydrothermal fluids in Early Archean chert: Evidence from silicon isotopes. Geology 35, 939-942.

VAn Den Boorn, S.H.J.M., VAn Bergen, M.J., Vroon, P.Z., De Vries, S.T., NiJMAN, W. (2010) Silicon isotope and trace element constraints on the origin of $\sim 3.5$ Ga cherts: implications for Early Archaean marine environments. Geochimica et Cosmochimica Acta 74, 1077-1103.

Von Strandmann, P.A.E.P., Opfergelt, S., LaI, Y.-J., Sigfússon, B., Gislason, S.R., BurTon, K.W. (2012) Lithium, magnesium and silicon isotope behaviour accompanying weathering in a basaltic soil and pore water profile in Iceland. Earth and Planetary Science Letters $339,11-23$.

Zambardi, T., Poitrasson, F., Corgne, A., Méheut, M., Quitté, G., ANAND, M. (2013) Silicon isotope variations in the inner solar system: Implications for planetary formation, differentiation and composition. Geochimica et Cosmochimica Acta 121, 67-83. 